\title{
INFLUENCE OF SANITARY - DOMESTIC CONDITIONS IN THE RURAL SETTLEMENTS OF DNEPROPETROVSK REGION ON THE PEASANTS' HEALH
}

DOI: 10.36740/WLek202002113

\author{
Luibov V. Hryhorenko', Serhii V. Abramov², Volodymyr M. Baibakov², Valerii A. Digtiar', Dmytro M. Lukianenko \\ 'STATE INSTITUTION “DNIPROPETROVSK MEDICAL ACADEMY MINISTRY OF HEALTH OF UKRAINE”, DNIPRO, UKRAINE \\ ²NIPRO MEDICAL INSTITUTE OF TRADITIONAL AND NON-TRADITIONAL MEDICINE, DNIPRO, UKRAINE
}

\begin{abstract}
The aim: Implementation results of sociological survey to the practice of hygienic researches at the subjective estimation of the drinking water quality and sanitary conditions of people's life.

Materials and methods: At our study was used standardized "Questionnaire survey about quality of piped drinking water, which enters to the building (apartment)", which contained 25 questions. In the sociological survey were participated 150 respondents.

Results: Peasants of Dnepropetrovsk region considered that the following indicators of drinking water quality impact on their health: deterioration quality of piped drinking water, smell $-22.6 \%$, color $-14.6 \%$, rust $-13.3 \%$, precipitate $-8.0 \%$, turbidity and suspended solids $-10.6 \%$, taste and aftertaste $-13.3 \%$, foam and impurities -10.6 $\%(p<0.05)$. Some of peasants ( $14.6 \%)$ have unsatisfactory sanitary conditions, living on $5-6$ persons in 1 rooms flat $(p<0.05)$.

Conclusions: Results of sociological survey shown that among rural residents increased the demand for a consumption of pre-treated drinking water, due to the deterioration quality of tap water in the rural area. It was determined, that increased frequency of use the bottled drinking water - daily it was used by 13 rural respondents (17.3\%), once a week - 21 respondents (28\%), 2-3 times a week -8 respondents (10.6\%).
\end{abstract}

KEY WORDS: quality and safety indexes; respondents; experimental and control group; questionnaire; sociological survey

Wiad Lek. 2020;73(2):278-284

\section{INTRODUCTION}

Safe potable water is essential for good health. Worldwide, children and adults especially in the developing countries are suffering from various water-borne diseases $[1,2,3]$. Problem of providing drinking water guaranteed quality is widely inspread not only for population of peri-urban communities $[4,5,6]$, but also in many regions of Ukraine, especially in the rural settlements of Dnepropetrovsk region $[7,8,9,10]$. Therefore, in the aspect of legal innovations in the field of preventive medicine the implementation results of sociological survey to the practice of hygienic researches during analyses of the drinking water quality and sanitary conditions of people life is a vital necessity problem.

\section{THE AIM}

Purpose of research is implementation results of sociological survey to the practice of hygienic researches at the subjective estimation of the drinking water quality and sanitary conditions of people's life.

\section{MATERIALS AND METHODS}

At our study was firstly used standardized "Questionnaire survey about quality of piped drinking water, which enters to the building (apartment)", which contained 25 questions. In the sociological survey were participated 150 respondents (75 - peasants and 75 city - dwellers). The basic criteria were: age of adult population (men and women), varied from 35 to 55 years; period of residence in this region - from 5 to 10 years and over 10 years; exposition of drinking water - from 5 to 10 years and over 10 years. Long - term period of residence was observed at the $76 \%$ of peasants and $77.3 \%$ of city - dwellers $(p<0.05)$. Most of our studies found that the quantity of respondents with up to 10 years period of water exposition was higher in both groups and varied from $22.6 \%$ to $24 \%$. According to the results of sociological survey, average age of rural residents was $33.33 \pm 0.52$ years, compared with city - dwellers $35.07 \pm 0.54$ years (Table I).

In order to carry out objective indicators as well as quality of potable water we conducted functional zoning rural settlements of Dnepropetrovsk region into two groups: experimental and control. Experimental group covered territories with agricultural activity, over 2583.9 ha ( $81 \%$ of Dnepropetrovsk region), which were subdivided into 4 agricultural centers inside the settlements: Apostolovskyi, Kryvorozskyi, Pavlogradskyi and Nikopolskyi. Control zone covered Central zone of urbanization, $18 \%$ of Dnepropetrovsk region, and includes Dnipro city. 
Table I. Distribution of respondents by age and gender groups (\%)

\begin{tabular}{|c|c|c|c|}
\hline Characteristic & & Peasants & City - dwellers \\
\hline \multirow{5}{*}{ Age, years } & $18-29$ & 31 (41.3\%) & $26(34.6 \%)$ \\
\hline & $30-39$ & $24(32.0 \%)$ & $27(36 \%)$ \\
\hline & $40-49$ & $16(21.3 \%)$ & $12(16 \%)$ \\
\hline & $50-59$ & $3(4.0 \%)$ & $7(9.3 \%)$ \\
\hline & 60 and more & $1(1.3 \%)$ & $3(4.0 \%)$ \\
\hline Totally & & 75 (100\%) & 75 (100\%) \\
\hline $\mathrm{p}$ & & & \\
\hline Average age $(M \pm m)$ & & $33.33 \pm 0.52$ years & $35.07 \pm 0.54$ years \\
\hline \multirow{2}{*}{ Gender } & Men & $36(48.0 \%)$ & $43(57.3 \%)$ \\
\hline & Women & 39 (52.0\%) & $32(42.6 \%)$ \\
\hline Totally & & 75 (100\%) & 75 (100\%) \\
\hline $\mathrm{p}$ & & & \\
\hline
\end{tabular}

Note. ${ }^{*} \mathrm{p}$ - significance of differences between groups by criterion $X^{2}$.

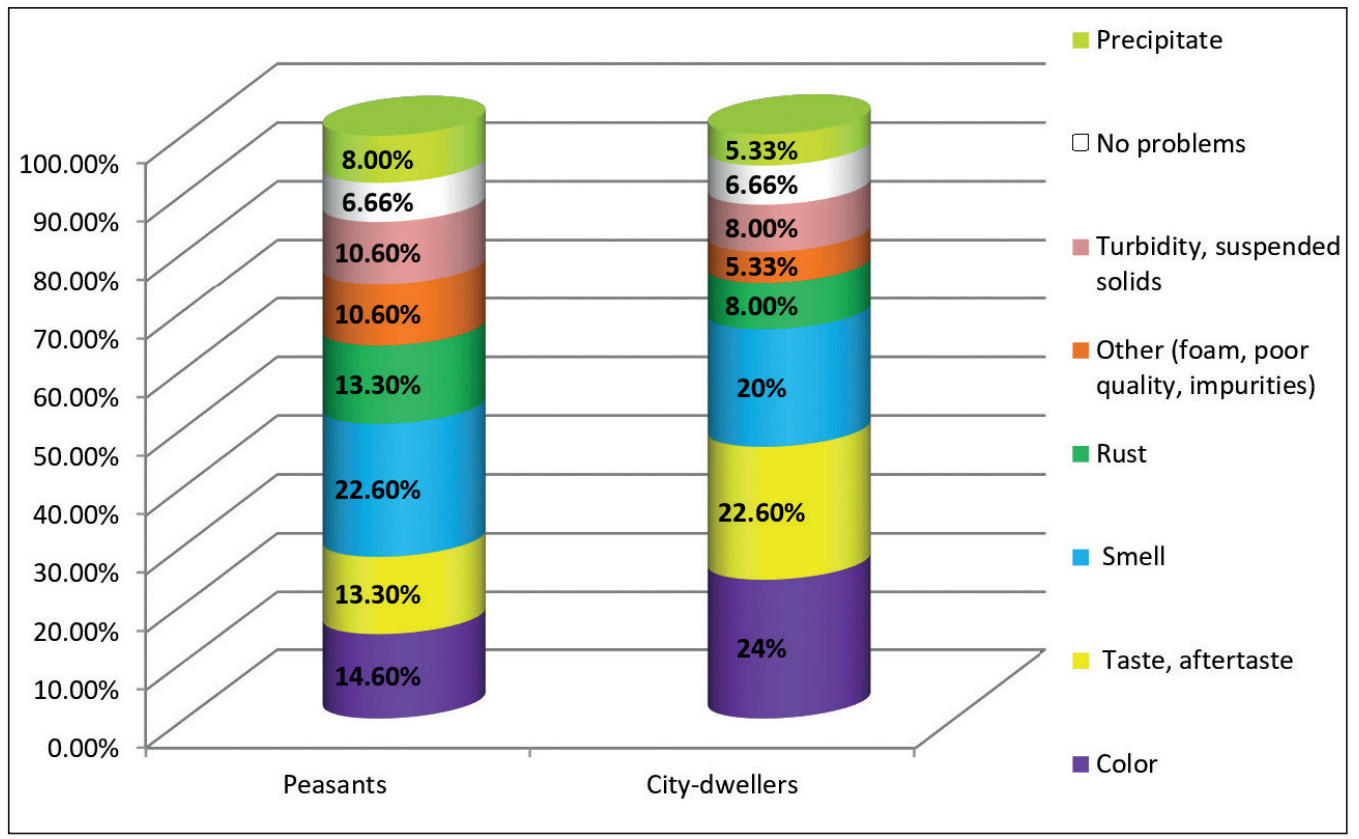

Fig. 1. Basic problems, associated with using of tap drinking water among rural and urban residents in Dnipropetrovsk region.

Retrospective study was carried out during 2014 - 2018 years. In our research was used such methods as retrospective studies, sociological, statistical. Statistical processing was carried out with the use of package STATISTICA 6.1 (serial number AGAR 909E415822FA). Statistical indicators were: number of observations (n), average means $(M)$, standard error $(m)$, relative values (\%). Level of statistical meaningfulness was accepted $(\mathrm{p}<0.05)$. Bioethics Commission on the protocol of Committee on Biomedical Ethics in the Dnipropetrovsk Medical Academy Ministry of Health of Ukraine (№ 5 from April 10, 2019) were not revealed any violations of the moral and ethical norms during research work.

\section{RESULTS AND DISCUSSION}

Our findings have been shown, that every 37 of 75 peasants, i.e. $49.3 \%$ of respondents were drinking mainly bottled water, as compared to the city - dwellers: 42 persons, i.e. $56 \%(\mathrm{p}<0.05)$. On the other hand, majority of peasants $50.6 \%$ weren't use bottled water $(\mathrm{p}<0.05)$. Rural population rarely used mineral water for drinking purposes, as shown $62.6 \%$ of peasants; the minority of peasants $-37.3 \%$ used mineral water for treatment purposes. Among city - dwellers only $61.3 \%$ didn't use mineral water for therapeutic purposes. The second stage of our sociological servey was ranking adult population in both groups in order to study their point of view towards different types of bottled water and drinking water purifiers. On the first rank were $58.9 \%$ of peasants, which were used for drinking and cooking purposes bottled water, as compared to $41.1 \%$ of city - dwellers. On the second rank were $20.6 \%$ of peasants, who prefer to use domestic filters $(\mathrm{p}<0.05) ; 10 \%$ of respondents used unboiled tap water $(\mathrm{p}<0.05)$. 
Table II. Respondents' answers from Central zone of urbanization on the question “Describe problems, associated with using of drinking water in Your community (\%)

\begin{tabular}{ccc}
\hline Proposed variant of answer & Peasants & City- dwellers \\
\hline Color & $11(14.6 \%)$ & $18(24 \%)$ \\
\hline Taste, aftertaste & $10(13.3 \%)$ & $17(22.6 \%)$ \\
\hline Smell & $17(22.6 \%)$ & $15(20 \%)$ \\
\hline Rust & $10(13.3 \%)$ & $6(8.0 \%)$ \\
\hline Other (foam, poor quality, impurities) & $8(10.6 \%)$ & $4(5.33 \%)$ \\
\hline Turbidity, st1spe11ded so lids & $8(10.6 \%)$ & $6(8.0 \%)$ \\
\hline No problems & $5(6.66 \%)$ & $5(6.66 \%)$ \\
\hline Precipitate & $6(8.0 \%)$ & $4(5.33 \%)$ \\
\hline Totally $(\mathrm{n}=150)$ & $75(100 \%)$ & $75(100 \%)$ \\
\hline $\mathrm{p}$ & $\mathrm{p}=0.224$ & \\
\hline
\end{tabular}

Note. $p$ - significance of differences between respondents answers in the experimental and control groups by a criterion $X^{2}-$ Pearson.

Table III. Respondents' answers from Central zone of urbanization on the question "Do you apply for drinking and cooking purposes bottled water?" (\%)

\begin{tabular}{ccc}
\hline Proposed variant of answer & Peasants & City - dwellers \\
\hline Yes & $31(20.6 \%)$ & $30(20 \%)$ \\
\hline No & $22(14.6 \%)^{*}$ & $15(10 \%)^{*}$ \\
\hline Sometimes & $22(14.6 \%)^{*}$ & $30(20 \%)^{*}$ \\
\hline Totally $(\mathrm{n}=150)$ & $75(100 \%)$ & $75(100 \%)$ \\
\hline $\mathrm{p}$ & $\mathrm{p}<0.05$ & \\
\hline
\end{tabular}

Note. $p$ - significance of differences between respondents answers in the experimental and control groups by a criterion $X^{2}-$ Pearson.

Table IV. Respondents' answers from Central zone of urbanization on the question "Do you use domestic filter for purification of drinking water?" (\%)

\begin{tabular}{ccc}
\hline Proposed variant of answer & Peasants & City - dwellers \\
\hline No & $28(18.6 \%)^{*}$ & $21(14.0 \%)^{*}$ \\
\hline We have a separate tap for drinking water & $16(21.3 \%)^{*}$ & $23(15.3 \%)^{*}$ \\
\hline We have a domestic filter & $31(20.6 \%)^{*}$ & $31(41.3 \%)^{*}$ \\
\hline Totally $(\mathrm{n}=150)$ & $75(100 \%)$ & $75(100 \%)$ \\
\hline $\mathrm{p}$ & $\mathrm{p}<0.05$ &
\end{tabular}

Note. $p$ - significance of differences between respondents answers in the experimental and control groups by a criterion $X^{2}-$ Pearson.

Table V. Respondents' answers from Central zone of urbanization on the question "Do you use for drinking purposes a tap water?" (\%)

\begin{tabular}{ccc}
\hline Proposed variant of answer & Peasants & City - dwellers \\
\hline Yes & $15(10 \%)$ & $9(6.0 \%)$ \\
\hline No & $37(24.6 \%)^{*}$ & $42(28 \%)^{*}$ \\
\hline Sometimes & $23(15.3 \%)^{*}$ & $24(16 \%)^{*}$ \\
\hline Totally $(n=150)$ & $75(100 \%)$ & $75(100 \%)$ \\
\hline$p$ & $p<0.05$ & \\
\hline
\end{tabular}

Note. $p$ - significance of differences between respondents answers in the experimental and control groups by a criterion $X^{2}$ - Pearson.

Respondents were proposed several answers to the question "Do You clean water immediately befor using?" Our study shows that majority of peasants - $32 \%$ prefer to use domestic filter, $24 \%$ of respondents were applied bottled water $(\mathrm{p}<0.05)$. The minority of peasants carried out traditional methods of drinking water purification: $16 \%$ - boiling; $17.3 \%$ drinking tap water $(\mathrm{p}<0.05) ; 10.6 \%-$ precipitation $(\mathrm{p}<0.05)$. Similar trend was observed among city - dwellers. On the first rank were $33.3 \%$ of respondents, installing domestic filters; $29.3 \%$ of city - dwellers testing different types of bottled water $(\mathrm{p}<0.05)$; the least $17.3 \%$ of city inhabitants was defined to use boiled water; $12 \%$ tap water without any additional purification $(\mathrm{p}<0.05)$; $8 \%$ - drinking water after precipitation $(\mathrm{p}<0.05)$.

At the prevalence of drinking water sources, related to population of rural settlements of Dnepropetrovsk region, 


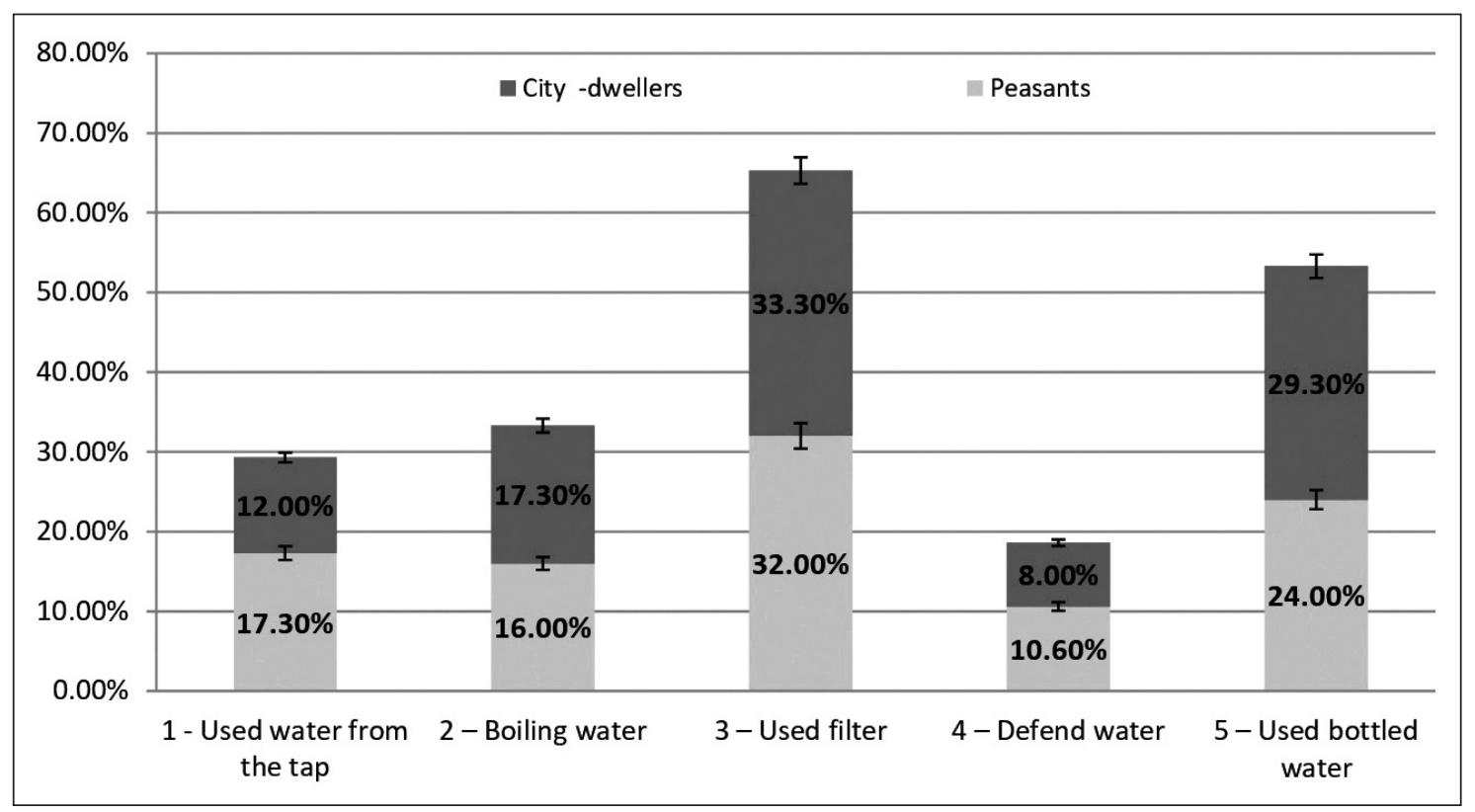

Fig. 2. Frequency of respondents' answers in the experimental and control groups on the question: "Do you purify water directly before using?" $(\mathrm{P} \pm \mathrm{mp} \%)$.

Table VI. Respondents' answers from (entral zone of urbanization on the question "What sources of water supply do you use in your community?" (\%)

\begin{tabular}{ccc}
\hline Proposed variant of answer & Peasants & City-dwellers \\
\hline Rural (city) water supply & $42(56 \%)$ & $50(66.6 \%)$ \\
\hline Well & $23(30.6 \%)$ & $4(5.33 \%)$ \\
\hline Open pond & $10(13.3 \%)$ & $21(28 \%)$ \\
\hline Total $(n=150)$ & $75(100 \%)$ & $75(100 \%)$ \\
\hline
\end{tabular}

Note. $p$ - significance of differences between respondents answers in the experimental and control groups by a criterion $X^{2}-P e a r s o n . p=0.199$

we include wells and their frequency of using - 30.6\%. Tap water was related to use at the $56 \%$ of peasants $(\mathrm{p}<0.05)$, $13.3 \%$ was recently reported from local additional sources as surface water $(\mathrm{p}<0.05)$. Exposure of water from the given sources was reported by city - dwellers in the interview as well as: additional sources such as surface water: $28 \%$ $(\mathrm{p}<0.05)$; wells $-5.33 \%$. In the standardized interview we carried out distance from the source of water to the population residence. Based on the sociological servey, we considered, that $25.3 \%$ of peasants were requested 15 - 25 meters; $57.3 \%$ of sources were located on the $30-50$ meters; $17.3 \%$ - up to 100 meters.

Most of peasants were dissatisfied with following indicators of drinking water quality: $22.6 \%$ with smell, $14.6 \%$ with color ( $\mathrm{p}<0.05$ ), $13.3 \%$ with rust, $8.0 \%$ with precipitate, $10.6 \%$ with turbidity and suspended solids, $13.3 \%$ with taste and aftertaste $(\mathrm{p}<0.05), 10.6 \%$ with foam, poor quality and impurities. Only $6.66 \%$ of respondents were satisfied with good-quality of drinking water (Figure 1).

City - dwellers noted deterioration of drinking water color $-24 \%$, taste and aftertaste $-22.6 \%$, smell $-20 \%$, precipitate $-5.33 \%$, rust $-8.0 \%$, and others (turbidity and suspended solids) $-8.0 \%$. About $5.33 \%$ of respondents considered other reasons for deterioration of drinking water quality, such as foam and impurities. Only $6.66 \%$ of citizens were satisfied with a quality of drinking water ( $\mathrm{p}$ $=0.224)$ (Table II).
Relation of residents from Central zone of urbanization in Dnipropetrovsk region to the different types of post-treated drinking water is presented in (Table III-V).

Primary, 20.6\% of peasants used for drinking and cooking purposes bottled water, compared with $20 \%$ of city dwellers $(p<0.05)$. Other respondents in the rural districts (20.6\%) used domestic filters for purification of drinking water. Significantly minority of respondents in both groups used for drinking purposes a tap water: $10 \%$ of peasants against $6.0 \%$ of city - dwellers ( $\mathrm{p}<0.05)$.

On the question "Do you purify water directly before using?" respondents were proposed several variants of answers. Results of our survey have been shown, that the vast majority of peasants $32.0 \%$ used domestic filter or the drinking bottled water $-24.0 \%$. Other peasants used traditional methods of water purification: $16.0 \%$ - boiling; $17.3 \%$ - tap drinking water; $10.6 \%$-defend water. As have been shown in (Figure 2), a similar trend was observed among the city - dwellers.

Among the different types of drinking water purification, city - dwellers prefer the use a domestic filter - $33.3 \%$, or the bottled water $-29.3 \%$, while other part of respondents used the boiled water $-17.3 \%$, or the tap water $-12.0 \%$, and defend water $-8.0 \%$. Water supply sources, used by the respondents in both groups, could be placed in the following ranked order. Peasants used drinking water from a network of water pipes - $56 \%$, wells - 30.6\%, $13.3 \%$ - from 
Table VII. Respondents' answers from Central zone of urbanization on the question "How many persons living in the Your apartment?" (\%)

\begin{tabular}{ccc}
\hline Proposed variant of answer & Peasants & City - dwellers \\
\hline 1 person & $6(8.0 \%)$ & $2(2.66 \%)$ \\
\hline 2 persons & $21(28 \%)$ & $26(34.6 \%)$ \\
\hline 3 persons & $20(26.6 \%)$ & $21(28 \%)$ \\
\hline 4 persons & $17(22.6 \%)$ & $21(28 \%)$ \\
\hline $5-6$ persons & $11(14.6 \%)$ & $5(6.66 \%)$ \\
\hline Totally $(\mathrm{n}=\mid 50)$ & $75(100 \%)$ & $75(100 \%)$ \\
\hline$p$ & $p=0.241$ &
\end{tabular}

Note. $p$ - significance of differences between respondents answers in the experimental and control groups by a criterion $X^{2}-$ Pearson.

Table VIII. Daily drinking water intake, liters per day (\%)

\begin{tabular}{ccc}
\hline Proposed variant of answer & Peasants & City - dwellers \\
\hline 1.5 liters & $1(1.33 \%)$ & 0 \\
\hline $2-5$ liters & $25(33.3 \%)$ & $44(58.6 \%)$ \\
\hline 6 -10 liters & $16(21.3 \%)$ & $11(14.6 \%)$ \\
\hline $20-45$ liters & $25(33.3 \%)$ & $5(6.66 \%)$ \\
\hline $50-100$ liters & $6(8.0 \%)$ & $9(12.0 \%)$ \\
\hline $200-300$ liters & $2(2.66 \%)$ & $6(8.0 \%)$ \\
\hline Totally $(\mathrm{n}=150)$ & $75(100 \%)$ & $75(100 \%)$ \\
\hline $\mathrm{p}$ & $\mathrm{p}=0.242$ & \\
\hline
\end{tabular}

Note. $p$ - significance level of differences by daily consumption of drinking water (litres/day) in the experimental and control groups by a criterion $X^{2}-$ Pearson.

open reservoirs. City - dwellers are significantly probably used water from local water pipe $-66.6 \%$ and $28 \%$ - from open reservoir, about $5.33 \%$ used drinking water from wells (Table VI).

According to the sociological survey, $25.3 \%$ of peasants had insufficient distance to a place of water supply - from 15 to 25 meters, which did not correspond to the Ukrainian National standards. On a distance from 30 to 50 meters were located sources of water supply at $57.3 \%$ of population in the experimental group and up 100 metres at $17.3 \%$ of the peasants, which was correspond to the hygienic standards.

As shown in (Figure 3), respondents in both groups were covered with central sewerage system: $65.3 \%$ of rural and $85.3 \%$ of urban population. Generally, 26 peasants (34.6\%) and 11 city - dwellers (14.6\%) were covered with decentralized sewage system.

On the next step of our research we carried out household conditions for residents in both groups of supervision. It was established, that 49 peasants having good sanitary conditions and were provided with centralized system of water supply and centralized sewage system $-32.6 \%(\mathrm{p}<0.05)$. Another $14.6 \%$ of peasants were residents in the suburban houses $(p<0.05)$ and $2.66 \%$ - in the detached houses $(\mathrm{p}<0.05)$. The household conditions of city-dwellers can be described as follows: $40 \%$ lived in apartments ( $\mathrm{p}<0.05), 7.33 \%$ - in the detached houses $(\mathrm{p}<0.05)$ and $2.66 \%$ - in suburban houses $(\mathrm{p}<0.05)$. We carried out hygienic estimation residents' appartment by the quantity of floors. The majority of peasants lived in the high-style appartments: from 6 - 16 storeys $38.6 \%$ to $1-5$ storeys flats $26.6 \%$. Another $29.3 \%$ of peasants were residents of the comfortable $1-5$ storeys suburban houses $(p<0.05) ; 5.33 \%$ of peasants lived in the cottages $(p<0.05)$. City-dwellers were provided with comfortable housing with centralized water system. Mostly, city-dwellers were located in the $6-16$ storeys flats: $52 \%$; in the cottages - 28\% ( $p<0.05) ; 5.33 \%$ - in the suburban houses $(\mathrm{p}<0.05)$. Results of sociological survey shown, that distribution by the quantity of respondents per 1 flat was following: 2 peasants per 1 flat $-28 \%$; 3 peasants per 1 flat $-26.6 \%$; 4 peasants per 1 flat $-22.6 \%$; $5-6$ peasants per 1 flat $-14.6 \%$; 1 peasant per 1 flat $-8.0 \%(\mathrm{p}<0.05)$. Most of city-dwellers lived on 2 people, as shown $34.6 \%$ of respondents; 3 city-dwellers per 1 flat $-28 \%$; 4 city-dwellers per 1 flat $-28 \%$; $5-6$ city-dwellers per 1 flat $-6.66 \%$; single respondents $-2.66 \%$ $(\mathrm{p}<0.05)$ (Table VII).

From hygienic point of view, we carried out analize quntity of water sinks in the apartments: $68 \%$ of peasants have been provided with 2 sinks; $13.3 \%$ - with 1 sink; $10.6 \%-3$ sinks $(\mathrm{p}<0.05)$. Minority of peasants in the rural settlements having $5-6$ sinks $-5.33 \%$. Analogical trend was observed among city-dwellers: $64 \%$ was provided with 2 sinks; another $22.6 \%$ of respondents used 3 sinks $(\mathrm{p}<0.05)$. On average 1 sink was located in the apartments of $13.3 \%$ of respondents in the control group. First rank position among city-dellers carried out 58.6\% of respondents, using drinking water $2-5$ liters per day on average $(p<0.05)$. Second rank takes the following 


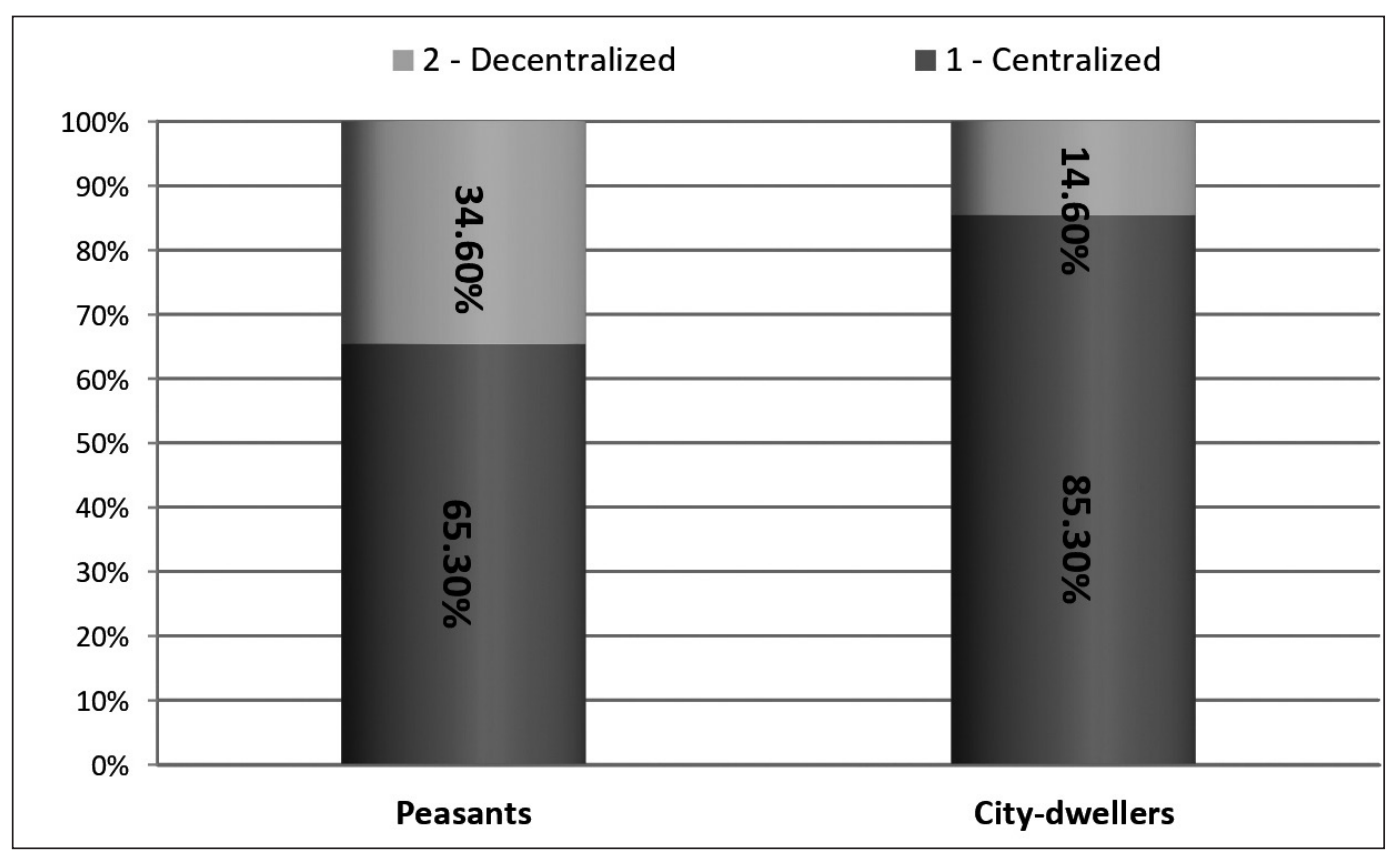

Fig. 3. Frequency of respondents' answers in the experimental and control groups on the question: «What type of sewerage system is carried out in Your

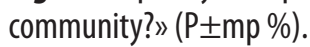

$14.6 \%$ of respondents, consuming from 6 to 10 liters of water $(\mathrm{p}<0.05)$. On the third place, as shown were located $12.0 \%$ of city-dwellers, which used up to 50-100 liters of water per day. Only $8.0 \%$ of respondents consume 200 300 litres of drinking water. Probably, peasants consumed 20-45 litres of drinking water per day 33.3\%. Daily intake of drinking water from 6 -10 liters per day was observed at $21.3 \%$ of peasants; from 50 to 100 liters $-8.0 \%$. Structure of water users by daily intake of drinking water is presented on (Figure 4).

Daily consumption of drinking water was varied at the minority of peasants: 1.5 liters per day $-1.33 \%$; $200-300$ liters consumed $-2.66 \%$ of respondents (Table VIII).

\section{CONCLUSIONS}

1. In our research in the field of preventive medicine were used implementation results of sociological survey, which helps to understand subjective estimation of the drinking water quality and sanitary conditions of people life, living in the different social conditions (in the rural districts and in the Dnipro city).

2. Peasants of Dnepropetrovsk region have been shown deterioration quality of piped drinking water by the following indicators as smell $-22.6 \%$, color $-14.6 \%$, rust $-13.3 \%$, precipitate $-8.0 \%$, turbidity and suspended solids $-10.6 \%$, taste and aftertaste $-13.3 \%$, foam and impurities $-10.6 \%(\mathrm{p}<0.05)$.

3. Our study indicates growth daily consumption of drinking water is related to peasants' population: from $2-5$ liters/ daily (33.3\%) to $20-40$ liters/daily (33.3\%). It was shown, that the peasants has been suported with centralized system of water supply and centralized sewage system (32.6\%) $(p<0.05)$. About $3 / 4$ of peasants $(34.6 \%)$ were covered with decentralized sewage systems. Majority of peasants lived in the 6-16 storeys apartments (38.6\%), $14.6 \%$ of peasants have unsatisfactory sanitary conditions, living on $5-6$ persons in 1 rooms flat $(\mathrm{p}<0.05)$.

\section{REFERENCES}

1. Prasad N.R., Child survival in rural areas. Book. New Delhi, India: Anmol. Publications, 1997, $196 \mathrm{p}$.

2. Water and health in Europe: a joint report from the European Environment Agency and the WHO Regional Office for Europe. Udited by Bartram Jamie et al. WHO Regional publications European series. World Health Organization: Copenhagen, 2002; 93:222.

3. Water quality criteria. Drinking water health advisories. Washington: U.S. Environmental Protection Agency, 2005. Electronic Book [Asses mode] http://www.epa.gov/waterscience/drinking/

4. Aktymbayeva A.S., Ableeva A.G., Aktymbayeva B.I., Evaluation of Alakol Lake Ecosystem Sustainability Under Conditions of Antropogenic Buren in the Basin Proceedings of the IWA 6th Eastern European Young Water Professionals Conference "EAST Meets WEST" Istanbul 2014; 150-168.

5. Barnes A.N., Anderson J.D., Mumma J., Mahmud Z.H., The association between domestic animal presence and ownership and household drinking water contamination among peri-urban communities of Kisumu, Kenya, PLoS One. 2018; 13 (6): 13-18.

6. Talanov E.A., Aktymbayeva A.S., Modeling of change of a mineralization of water and ecological condition of Alakol lake, Materials of the international symposium. Alma-Ata 2001; 109-117.

7. Hryhorenko L.V., Analysis state of health population of children in the rural district of the industrial region of Ukraine, European Applied Sciences. 2013; 8: 31-32.

8. Hryhorenko L.V., Drinking water quality influence to the peasants morbidity in the Ukrainian settlements (by the results of sociological survey and correlation analyses), International Journal of Statistics and Actuarial Science. New York: Research Publishing Group, 2017; 1 (2): $46-54$. 
9. Hryhorenko L.V., Potable water quality in the Karachunyvskyi reservoir, Austrian Journal of Technical and Natural Sciences. 2014; 1: 40-45.

10. Hryhorenko L.V., Shchudro S.A., Shevchenko A.A., et al. Prevalence of diseases among children population in Dnepropetrovsk region (Ukraine), correlated with deterioration of drinking water quality, Georgian Medical News. 2017; 11 (272): 91-96.

Research work was carried out within a framework on the cathedral theme of the research work: "Scientific substantiation ecological and hygienic measures to prevent the negative influence of antropogenic factors on the environment and state of the population health", state registration number 0108U011276 (implementation period 2014-2018 years).

\section{ORCID and contributionship:}

Luibov V. Hryhorenko - 0000-0002-9517-5975 D, F

Serhii V. Abramov - 0000-0003-1697-913X C

Volodymyr M. Baibakov - 0000-0001-8632-103X ${ }^{B}$

Valerii A. Digtiar - 0000-0002-3182-2512 ${ }^{\mathrm{E}}$

Dmytro M. Lukianenko - 0000-0002-8245-2208 A

\section{Conflicts of interest:}

Authors declare no conflict of interest.

\section{CORRESPONDING AUTHOR Luibov V. Hryhorenko}

St. Kryvorizhstali, ap. 12, flat 35, 50051, Kryvyi Rih, Ukraine tel: +380680091847

e- mail: hryhorenkoluibov@ukr.net

Received: 22.05 .2019

Accepted: 19.12 .2019

A - Work concept and design, B - Data collection and analysis, C - Responsibility for statistical analysis,

D-Writing the article, $\mathbf{E}$-Critical review, $\mathbf{F}$ - Final approval of the article 